\title{
Corporate governance disclosure practices of banks- A study conducted for BSE 200 banks
}

Dr. J K Raju, Associate Professor, Institute of Management studies, Sivagangotri, Davanagere

Ms. Chaya Bagrecha, Assistant Professor, PG Department of Management studies,

S R N Adarsh College, Chamarajpet, Bangalore

\begin{abstract}
Governance of banks is crucial for growth and development of the economy. Hence a need was felt for a detailed study in corporate governance of banks. Through this research, an attempt (or) has been made, to fill these gaps and conduct an empirical study, to record the Corporate Governance practices of BSE 200 banking companies, for a period of five years. All the dimensions of governance have improved significantly during the post compulsion period as compared to the pre compulsion period. This is a positive outcome of the stand taken by SEBI, in making it compulsory for all listed companies to disclose governance related issues in their annual reports. All the banks have consciously attempted towards improving the CG disclosure practices, and this is clearly evident in the analysis.

"The primary purpose of corporate leadership is to create wealth legally and ethically. This translates to bringing a high level of satisfaction to five constituencies - Customers, Employees, Investors, Vendors and the Society-At-Large. The raison d'être of every corporate body is to ensure Predictability, Sustainability and Profitability of revenues year after year". ${ }^{1}$

N. R. Narayana Murthy (Founder, Infosys)

The concept of "Governance" is as old as human civilization. In simple terms, "Governance" means the process of decision making and the process by which decisions are implemented (or not implemented). Governance can be used in several contexts such as Corporate Governance, International Governance, National Governance, Local Governance and even e-governance. The word "Corporate Governance" has become a buzzword these days.
\end{abstract}

\section{A. Definitions}

Corporate Governance has been defined by many renowned Scholars and Institutions. A few of such definitions of Corporate Governance will give us a better understanding of the concepts from all possible perspectives.

J. Wolfensohn, president of the World bank, quotes" "Corporate Governance is about promoting corporate fairness, transparency and accountability"
Sir Adrian Cadbury in 'Global Corporate Governance Forum', World Bank, $2000^{3}$ has rightly said "Corporate Governance is concerned with holding the balance between economic and social goals and between individual and communal goals. The aim is to align as nearly as possible the interests of individuals, corporations and society"

Margaret Blair, in her book, 'Ownership and Control' - Rethinking Corporate Governance for the Twenty-first Century, 19954, describes Corporate

\footnotetext{
1 Retrieved from http://www.infosys.com/investors/corporate-governance/Pages/index.aspx

2 Financial Times, June 21, 1999) retrieved from www.heritageinstitute.com/governance/definitions.htm

3 Retrieved from www.corpgov.net/library/definitions.html

4 Retrieved from www.corpgov.net/library/definitions.html
} 
Governance as about "the whole set of legal, cultural, and institutional arrangements that determine what public corporations can do, who controls them, how that control is exercised, and how the risks and return from the activities they undertake are allocated."

Thus it can be said that, Corporate Governance is the set of processes, customs, policies, laws and institutions affecting the way a corporation is directed, administered or controlled. It also includes the relationships among the many players involved, that is, the stakeholders, and the goals for which the corporation is governed. The principal players are the shareholders, management and the board of directors. Other stakeholders include employees, suppliers, customers, banks and other lenders, regulators, the environment and the community at large.

At its broadest, Corporate Governance encompasses the framework of rules, relationships, systems and processes within and by which fiduciary authority is exercised and controlled in corporations.

\section{B. Clause 49 of the listing agreement issued by SEBI}

The regulatory framework governing the boards of directors of Indian corporations is set out in Chapter II (sections 252 to 269) of the Companies Act, 1956. In addition, Clause 49 of the Listing Rules issued by SEBI, which is implemented on a "comply or explain" basis, also provides a framework for the board of directors of listed companies.

These requirements, as required by SEBI under clause 49 of the listing agreement have formed the basis of the research undertaken.

\section{Why corporate governance in banks?}

Banks are a critical component of the economy, as they are the providers of finance to the industry and trade. Their importance can also be understood by the fact that they are the most regulated, at the same time most protected. Banks, in a broad sense, are institutions whose business is handling other people's money ${ }^{5}$ Banks are corporations themselves. It is therefore very important that banks have strong Corporate Governance practices. Banks' Corporate Governance gets reflected in Corporate Governance of firms they lend to. Thus, governance of banks is crucial for growth and development of the economy.

Hence a need was felt for a detailed study in corporate governance of banks. Through this research an attempt (or) has been made to fill these gaps and conduct an empirical study to record the Corporate Governance practices of BSE 200 banking companies for a period of five years (2004-05 to 2008-09).

\section{Research Problem}

Corporate governance is about, the way in which boards oversee the running of a company, by its managers, and how board members are in turn accountable to shareholders and the company. Good corporate governance plays a vital role in underpinning the integrity and efficiency of financial markets. On the other hand, poor corporate governance weakens a company's potential and at worst can pave the way for financial difficulties and even fraud. Corporate governance has gradually evolved into a conscience approach from the traditional compliance one, in all sectors of the economy. It has gained utmost importance in banks due to various reasons.

Bank behaviour influences economic outcomes. Banks mobilize and allocate society's savings. Especially in developing countries, banks can be very important source of external financing for firms. Banks exert Corporate Governance over firms, especially small firms that have no direct access to financial markets. Banks' Corporate Governance gets reflected in Corporate Governance of firms they lend to. ${ }^{6}$ Thus, governance of banks is crucial for growth and development of the economy.

Specifically, this research tries to answer the following: Have the issuance of corporate governance regulations by the SEBI been followed by banks in totality and right spirit?

5 Greener, Michael The penguin dictionary of Commerce,(1973) Reprints

6 Stijn Claessens Senior Adviser, Operations and Policy Department Financial Sector Vice-Presidency, World BankCorporate Governance of Banks: Why it is important, how it is special and what it implies Retrieved from www.oecd.org/dataoecd/19/27/34080764 


\section{E. Literature Review}

Numerous recent studies emanating from academic circles show that, good Corporate Governance increases valuations and boosts the bottom line. A vast amount of literature is derived to understand the importance of difference between Corporate Governance and firms' value or performance. Most of these studies had focused on particular aspects of Corporate Governance.

\section{$\checkmark$ Klapper and Love (2004) ${ }^{7}$}

Employ a composite of 57 qualitative binary questions provided by Credit Lyonnais Securities Asia (CSLA) to develop their index for 14 emerging markets. These questions fall in seven categories of governance: discipline, transparency, independence, accountability, responsibility, fairness, and social awareness.

\section{$\checkmark$ Brown and Caylor (2004)}

They created a corporate governance index using data provided by 'Institutional Shareholder Services'. Their Index 'Gov-Score' was a composite measure of 51 governance provisions covering eight categories.

\section{$\checkmark$ Muhammed Hossain (2004) ${ }^{9}$}

The study reports the level and extent of the Corporate Governance disclosure of the banking companies in India. The researcher has identified 57 items of information, both mandatory and non mandatory need, to be disclosed under the clause 49 in the corporate governance report. The study revealed that, Indian banks have very high level of compliance in corporate governance disclosure. The corporate governance disclosure score ranges fall between 95 and 69 . The findings indicate that assets, ownership and financial performance variables are significant, and other variables such as age, board composition and complexity of business are insignificant in explaining the level of corporate governance disclosure.

\section{F. Objective of the Study}

To find out the disclosure levels of the selected banks with reference to mandatory and non mandatory requirements of SEBI guidelines during the pre compulsion and post compulsion period. (Presence or Absence of attributes in the Corporate Governance Report)

\section{G. Hypothesis Development}

To get a statistically significant result of this objective, the following null hypotheses were set up.

\section{Null Hypothesis 1}

$\mathbf{H}_{1}$ : There is no difference in the corporate governance disclosure levels of banks, between the pre compulsion and post compulsion period.

This is split into two sub hypothesis.

\section{Null hypothesis $1(a)$}

a. $H_{1(\mathrm{a})}$ : There is no difference in the disclosure levels of individual attributes (A to $\mathrm{J}$ ) of corporate governance of banks, between the pre compulsion and post compulsion period.

\section{Null hypothesis 1(b)}

a. $H_{1(b)}$ : There is no difference in the corporate governance scores of banks, between the pre compulsion and post compulsion period.

Null hypothesis $1(a)$ is further divided into 10 sub hypotheses.

\section{Null hypothesis $1(\mathrm{a}-\mathrm{i})$}

$\mathbf{H}_{1(\mathrm{a}-\mathrm{i})}$ : There is no difference in the disclosure levels of Governance philosophy of banks, between the pre compulsion and post compulsion period.

\footnotetext{
Corporate Governance, Investor Protection and Performance in Emerging Markets" March 2002 World Bank Policy Research Working Paper No. 2818

8 Brown and Caylor "Corporate Governance and Firm Performance" http://papers.ssrn.com/sol3 /papers.cfm?abstract_id=586423

9 Mohammed Hossain (March, 2004)The corporate governance reporting exercise: the portrait of a developing country, International Journal of Business Research,
} 


\section{Null hypothesis $1(a-i i)$}

$\mathbf{H}_{1 \text { (a-ii) }}$ : There is no difference in the disclosure levels of board of directors, between the pre compulsion and post compulsion period.

Null hypothesis 1 (a-iii)

$\mathbf{H}_{1 \text { (a-iii) }}$ : There is no difference in the disclosure levels of audit committee of banks, between the pre compulsion and post compulsion period.

Null hypothesis 1 (a-iv)

$\mathbf{H}_{1 \text { (a-iv) }}$ : There is no difference in the disclosure levels of remuneration committee of banks, between the pre compulsion and post compulsion period.

\section{Null hypothesis $1(a-v)$}

$\mathbf{H}_{1(\mathrm{a}-\mathrm{v})}$ : There is no difference in the disclosure levels of shareholders' committee of banks, between the pre compulsion and post compulsion period.

\section{Null hypothesis 1(a-vi)}

$\mathbf{H}_{1(\text { a-vi) }}$ : There is no difference in the disclosure levels of general body meeting of banks, between the pre compulsion and post compulsion period.

\section{Null hypothesis 1(a-vii)}

$\mathbf{H}_{1 \text { (a-vii) }}$ : There is no difference in the disclosure levels of other disclosures of banks, between the pre compulsion and post compulsion period.

\section{Null hypothesis 1(a-viii)}

$\mathbf{H}_{1 \text { (a-viii) }}$ : There is no difference in the disclosure levels of means of communication of banks, between the pre compulsion and post compulsion period.

\section{Null hypothesis 1 (a-ix)}

$\mathbf{H}_{1(\text { a-ix } x}:$ There is no difference in the disclosure levels of general shareholder information of banks, between the pre compulsion and post compulsion period.

Null hypothesis $1(a-x)$

$\mathrm{H}_{1(\mathrm{a}-\mathrm{x})}$ : There is no difference in the disclosure levels of non-mandatory requirements of banks, between the pre compulsion and post compulsion period.

\section{H. Operational definition:}

i. Corporate Governance Score: is an unweighted disclosure index. This approach is adopted in the study as other researchers used this approach. (Wallace, 1987; Cooke, 1991 and 1992; Karim, 1995; Hossain et al., 1994; Ahmed and Nicholls, 1994; and Hossain, 1999.

The CG Scores are derived by the formula:

$$
\text { CG Score }=\sum d_{i} \text { where } i=A \text { to } \mathbf{J}
$$

Where,

$d i=1$ if the item of governance is displayed and di=0 if it is not displayed. All the items of disclosure are given equal weights, indicating equal importance.

And,
$A=$ Governance philosophy of the company
$\mathrm{B}=$ Board of directors
$\mathrm{C}=$ Audit committee
$\mathrm{D}=$ Remuneration committee
$\mathrm{E}=$ Shareholders' committee
$\mathrm{F}=$ General body meeting,
$\mathrm{G}=$ Other Disclosures
$\mathrm{H}=$ Means of communication
$\mathrm{I}=$ General shareholder information and
$\mathrm{J}=$ Non-Mandatory Requirements

\section{i. Scope of the Study}

The study covers the annual reports of 25 banks from the BSE 200. The banks included are:

\section{Table 1 Banks Included In The Study}

1 Allahabad Bank,

2 Andhra Bank

3 AXIS Bank Ltd.

4 Bank of Baroda

5 Bank Of India

6 Bank Of Maharastra

7 Canara Bank

8 Federal Bank Ltd.

9 HDFC Bank Ltd.

$10 \quad \mathrm{ICICl}$ Bank Ltd.

11 Indian Bank

12 Indian Overseas Bank 
13 Industrial Dev Bank of India

14 Indusind Bank

15 Ing Vysya Bank

16 Karnataka Bank Ltd.

17 Kotak Mahindra Bank Ltd.

18 Oriental Bank of Commerce

19 Punjab National Bank

20 State Bank of India

21 Syndicate Bank

22 Union Bank of India

23 Vijaya Bank

24 Yes Bank Ltd.

25 UCO bank

\section{j. Time Frame}

The reports were studied for the years 2004-05, 2005-06, 2006-07, 2007-08 and 2008-09. The logic behind selecting these years is explained as under:

2004-05: This was the period when SEBI required all the listed companies to report on corporate governance in their annual reports, but was not mandatory. The requirement was suggestive in $n$ ature.

2005-06: SEBI directed that all the listed companies needed to mandatorily comply with corporate governance disclosure requirements, as per clause 49 of the listing agreement.

2006-07, 2007-08 and 2008-09: to understand the disclosure practices of the banks during this period, and also to check its impact on their performance.

\section{k. Research design}

\section{Type of research:}

This is a combination of descriptive and analytical research.

\section{Data sources}

The annual reports of banks, more specifically, the corporate governance reports and financial statements were the source of all data that are required to study the governance practices of banks. The data was collected from the annual reports of these banks. Capitaline database ${ }^{10}$ and websites of the banks proved to be useful in collecting the reports. Primary data does not form a part of this study.

\section{Population size}

The study covers all the 25 banks from the BSE 200 group for the period 2004-05 to 2008-09. Therefore 125(25banks*5years) annual reports were collected and studied.

An elaborate spreadsheet was prepared for data entry. The presence or absence of the variables was marked using 1 and 0.75 variables under 10 different headings were identified for the research. Along with these items, other vital information relating to these banks were recorded for all the banks over the study period.

\section{Analytical Techniques}

MS Excel and SPSS packages were used for the purpose of data collection and data analysis.

\section{Limitations of the Study}

(i) Since the study covers only banks, the findings cannot be generalized to the other sectors.

(ii) Though the study covered all the 25 banks in the BSE200 group, it may not be representative of the banking sector in India.

(iii)As good governance is still hard to gauge, complying with all the rules do not necessarily mean a firm is being well run.

(iv)The score only indicates the presence or absence of a particular issue in the Corporate Governance report of the bank. What it fails to indicate is whether the count is favourable or not, e.g., fines paid, contingent liability, pending complaints, etc.

(v) It is assumed that Governance and Performance coexist on the timeline. However, good Corporate Governance and high performance of the company do not occur in the same period. Performance may have a lag effect of one to three years, but that is not established.

(vi)The CG report records only the number of meetings and attendance of directors. but proceedings and outcome of those meetings which has an impact on the future of the bank is not considered.

10 They deliver the highest quality market data and financial information available on securities, derivatives and commodities traded on Indian stock markets. www.capitaline.com. 
m. Key findings

Table 2 CG Scores of Banks

\begin{tabular}{|c|c|c|c|c|c|c|}
\hline Name of the bank & 2004-05 & 2005-06 & 2006-07 & 2007-08 & 2008-09 & Bank Average \\
\hline Allahabad Bank & 46 & 52 & 55 & 54 & 55 & 52.4 \\
\hline Andhra Bank & 43 & 53 & 58 & 62 & 51 & 53.4 \\
\hline AXIS Bank Ltd. & 47 & 50 & 51 & 57 & 60 & 53 \\
\hline Bank of Baroda & 49 & 55 & 54 & 54 & 61 & 54.6 \\
\hline Bank Of India & 41 & 46 & 47 & 56 & 52 & 48.4 \\
\hline Bank of Maharashtra & 45 & 43 & 50 & 51 & 47 & 47.2 \\
\hline Canara Bank & 49 & 62 & 62 & 59 & 60 & 58.4 \\
\hline Federal Bank Ltd. & 42 & 46 & 44 & 51 & 53 & 47.2 \\
\hline HDFC Bank Ltd. & 51 & 56 & 57 & 61 & 59 & 56.8 \\
\hline ICICI Bank Ltd. & 57 & 59 & 55 & 61 & 68 & 60 \\
\hline Indian Bank & DNA & 9 & 56 & 51 & 50 & 33.2 \\
\hline Indian Overseas Bank & 49 & 57 & 58 & 60 & 53 & 55.4 \\
\hline Industrial Dev Bank of India & 52 & 51 & 52 & 52 & 53 & 52 \\
\hline Indus Ind bank & 47 & 55 & 57 & 61 & 59 & 55.8 \\
\hline Ing Vysya Bank & 52 & 59 & 56 & 55 & 55 & 55.4 \\
\hline Karnataka Bank Ltd. & 21 & 8 & 54 & 52 & 53 & 37.6 \\
\hline Kotak Mahindra Bank Ltd. & 48 & 53 & 58 & 61 & 60 & 56 \\
\hline Oriental Bank of Commerce & 49 & 50 & 50 & 54 & 54 & 51.4 \\
\hline Punjab National Bank & 53 & 52 & 55 & 54 & 58 & 54.4 \\
\hline State Bank of India & 45 & 55 & 53 & 54 & 57 & 52.8 \\
\hline Syndicate bank & 44 & 47 & 53 & 55 & 56 & 51 \\
\hline Uco Bank & 44 & 51 & 52 & 55 & 55 & 51.4 \\
\hline Union Bank of India & 41 & 48 & 51 & 57 & 58 & 51 \\
\hline Vijaya Bank & 46 & 50 & 54 & 57 & 52 & 51.8 \\
\hline Yes Bank Ltd. & 21 & 54 & 60 & 60 & 58 & 50.6 \\
\hline Yearly average & 43.28 & 48.84 & 54.08 & 56.16 & 55.88 & 51.648 \\
\hline
\end{tabular}

(Source: Data collected from annual reports of banks) 
The above table shows the disclosure levels of the banks during the study period. A clear improvement in the disclosure index from 2005 to 2007 is visible. Thereafter, there is a marginal decline in the disclosure level, at the end of 2009. But, overall there is a gain during the study period from a CG score of 43.28 to 55.88 .

This is depicted in the graph shown below.

\section{Graph 1 Average CG Score}

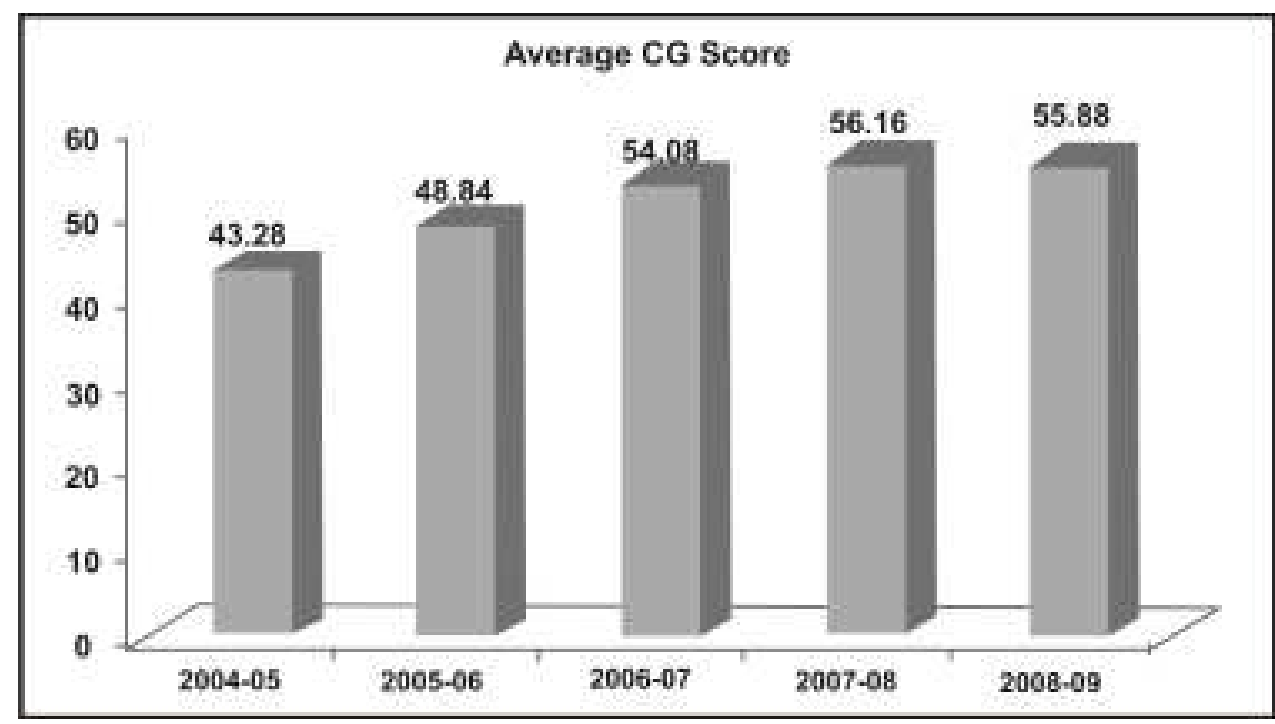

The components of variation are identified in the next table.

Table 3 Disclosure of Individual Attributes of Corporate Governance

\begin{tabular}{|l|c|c|c|c|c|c|c|c|c|c|}
\hline Year & A & B & C & D & E & F & G & H & I & J \\
\hline $\mathbf{2 0 0 4 - 0 5}$ & 1.56 & 5.2 & 3.16 & 1.52 & 3.68 & 1.8 & 1.8 & 2.84 & 11.8 & 9.92 \\
\hline $\mathbf{2 0 0 5 - 0 6}$ & 1.6 & 5.28 & 3.04 & 1.6 & 4 & 2.48 & 3 & 3.2 & 12.6 & 12 \\
\hline $\mathbf{2 0 0 6 - 0 7}$ & 1.8 & 5.6 & 3.32 & 2 & 4.56 & 2.64 & 3.36 & 3.4 & 14 & 13.4 \\
\hline $\mathbf{2 0 0 7 - 0 8}$ & 1.72 & 5.56 & 3.4 & 2.4 & 4.8 & 2.88 & 3.52 & 3.44 & 14.2 & 14.2 \\
\hline $\mathbf{2 0 0 8 - 0 9}$ & 1.88 & 5.68 & 3.4 & 2.52 & 4.8 & 2.76 & 3.48 & 3.32 & 14.1 & 13.9 \\
\hline Average & 1.71 & 5.46 & 3.26 & 2.01 & 4.37 & 2.51 & 3.03 & 3.24 & 13.4 & 12.7 \\
\hline Maximum & 2 & 6 & 4 & 5 & 5 & 6 & 4 & 5 & 16 & 22 \\
\hline \%disclosure & 85 & 91 & 81 & 40 & 87 & 41 & 75 & 64 & 83 & 57 \\
\hline
\end{tabular}

(Source: Data collected from annual reports of banks) 
The above table shows that disclosure of CG as required by SEBI is being followed by banks satisfactorily, but the ones relating to General body meeting, Disclosures, Means of communication, General shareholder information and Non-Mandatory Requirements have come down in 2008-09, when compared to 2007-08.

The percentage disclosure of all the attributes is depicted in the following graph.

\section{Graph 2 Percentage disclosure of attributes}

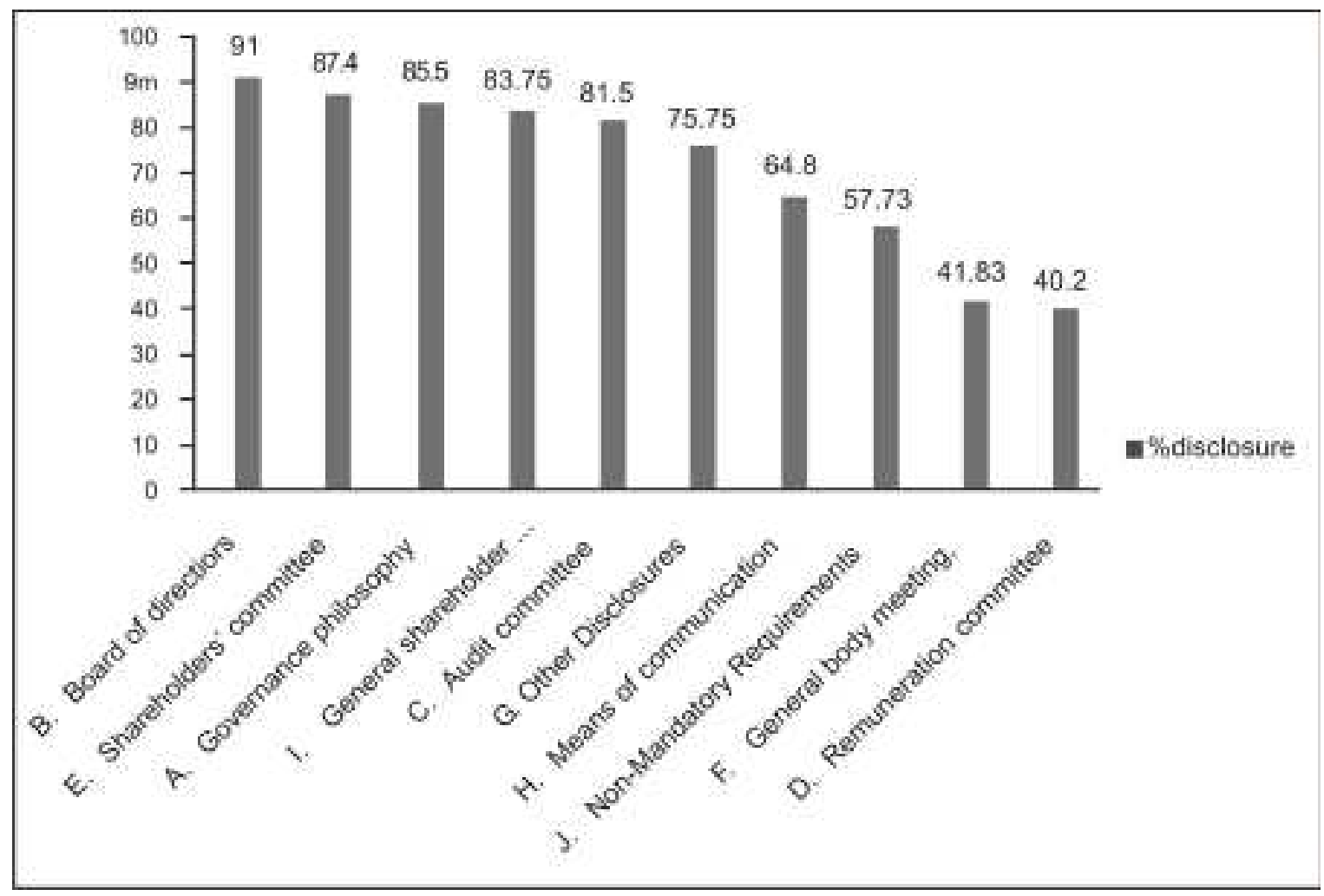

The key findings relating to disclosure of these broad attributes of governance, are presented here.

The calculations and the consolidated result, relating to hypothesis 1(a) are given below. 
Table 4 Differences in attributes between pre and post compulsion periods-Statistics

\begin{tabular}{|c|c|c|c|c|c|c|c|}
\hline \multirow[t]{2}{*}{ Attributes } & \multicolumn{2}{|c|}{$\begin{array}{l}\text { Pre-CG Disclosure } \\
\text { Practices }(\mathrm{N}=50)\end{array}$} & \multicolumn{2}{|c|}{$\begin{array}{l}\text { Post-CG Disclosure } \\
\text { Practices }(\mathrm{N}=75)\end{array}$} & \multicolumn{2}{|c|}{ ANOVA } & \multirow[t]{2}{*}{$\begin{array}{c}\text { Accept/ } \\
\text { Reject HO }\end{array}$} \\
\hline & Mean & $\begin{array}{c}\text { Std. } \\
\text { Deviation }\end{array}$ & Mean & $\begin{array}{c}\text { Std. } \\
\text { Deviation }\end{array}$ & $\begin{array}{c}F \\
\text { Ratio }\end{array}$ & $\begin{array}{l}\text { Sig. } \\
\text { Value }\end{array}$ & \\
\hline 1 & 2 & 3 & 4 & 5 & 6 & 7 & 8 \\
\hline Governance Philosophy & 1.58 & 0.76 & 1.80 & 0.46 & 4.042 & 0.047 & Reject $\mathrm{H}_{1(\mathrm{a}-\mathrm{i})}$ \\
\hline Board of Directors & 5.24 & 1.38 & 5.61 & 0.66 & 4.118 & 0.045 & Reject $\mathrm{H}_{1(\text { a-ii) }}$ \\
\hline Audit Committee & 3.10 & 0.86 & 3.37 & 0.49 & 5.101 & 0.026 & Reject $\mathrm{H}_{1(\text { a-iii) }}$ \\
\hline Remuneration Committee & 1.56 & 1.45 & 2.31 & 1.38 & 8.492 & 0.004 & Reject $\mathrm{H}_{1(\mathrm{a}-\mathrm{i} \mathrm{v})}$ \\
\hline Shareholders Committee & 3.84 & 1.61 & 4.72 & 0.61 & 18.575 & 0.000 & Reject $\mathrm{H}_{1(\mathrm{a}-\mathrm{v})}$ \\
\hline General Body meetings & 2.14 & 1.70 & 2.76 & 1.65 & 4.127 & 0.044 & Reject $\mathrm{H}_{1(\mathrm{a}-\mathrm{vi})}$ \\
\hline Disclosures & 2.40 & 1.34 & 3.45 & 0.79 & 30.420 & 0.000 & Reject $\mathrm{H}_{1(\text { a-vii) }}$ \\
\hline Means of Communication & 3.02 & 1.15 & 3.39 & 0.70 & 4.923 & 0.028 & Reject $\mathrm{H}_{1(\text { a-viii) }}$ \\
\hline $\begin{array}{l}\text { General Shareholder } \\
\text { information }\end{array}$ & 12.22 & 4.09 & 14.12 & 1.06 & 14.760 & 0.000 & Reject $\mathrm{H}_{1(\mathrm{a}-\mathrm{-} \mathrm{x})}$ \\
\hline $\begin{array}{l}\text { Non-Mandatory } \\
\text { Requirement }\end{array}$ & 10.96 & 3.41 & 13.84 & 2.67 & 27.875 & 0.000 & Reject $\mathrm{H}_{1(\mathrm{a}-\mathrm{x})}$ \\
\hline CG SCORE & 47.00 & 11.00 & 55.37 & 4.07 & 36.033 & 0.000 & Reject $\mathrm{H}_{1(\mathrm{~b})}$ \\
\hline
\end{tabular}

\section{(Source: Data collected from annual reports of banks)}

In the above table,

$\checkmark \quad$ Column 1 displays the broad attributes of corporate governance, whose disclosures were studied.

$\checkmark \quad$ Column 2 and 3 indicate the mean and standard deviation of disclosures, under these attributes during the pre disclosure period.

$\mathrm{N}=50$ indicates the number of annual reports studied during that period.

$\checkmark \quad$ Column 4 and 5 indicate the mean and standard deviation of disclosures, under these attributes during the post disclosure period.

$\mathrm{N}=75$ indicates the number of annual reports studied during that period.

$\checkmark \quad$ Column 6 and 7 indicate the ANOVA output values-F ratio and sig value

$\mathrm{F}$ ratio represents the ratio of variation of means between periods and within banks. As a rule of thumb, $\mathrm{F}$ Value greater than 4 leads to statistical significance of CG between the two periods, i.e., a significant difference in disclosure levels between the two periods. 
Sig indicates the significance level of $F$ test. Small sig values $(<0.05)$ indicate group differences, i.e., there is a significant difference in disclosure levels between the two periods.

$\checkmark \quad$ Column 8 indicates the result of $F$ test.

Thus, it can be said that there has been tremendous improvement in disclosure practices of banks, with respect to corporate governance. All the dimensions of governance have improved significantly during the post compulsion period, as compared to the pre compulsion period. This is a positive outcome of the stand taken by SEBI, in making it compulsory for all listed companies to disclose governance related issues, in their annual reports. All the banks have consciously attempted towards improving the CG disclosure practices, and this is clearly evident in the analysis.

\section{N. Conclusion}

The efforts of the government and SEBI, in making corporate governance a part of the Annual report has found tremendous success. Banks, big and small, old and new, profitable and not so profitable, are disclosing both mandatory and non-mandatory issues, to a very large extent. What remains to be done is that, it does not continue to be reported only in letter but also in spirit. As Adi Godrej said "Corporate governance in any organisation needs to be principle based and SMART- smart, moral, accountable, responsive and transparent. Corporate governance has to be principle-based not rule-based ${ }^{11}$. This will go a long way in building the confidence levels of stakeholders. 